\title{
Beyond the Reductionist Thinking-Doing
}

\section{by Fotis Theodridis}

The debate about the modern and the postmodern concerns the identity of the Western civilization, the very world of significations around which Western societies have bought themselves into being and constituted themselves as a particular civilization. Like any civilization, West has invested its significations with a whole universe of affections and intentions that give meaning to, inspire and orient individual and social action. A whole world, both social and subjective, has been created around them, and a whole world risks being overthrown every time they are questioned seriously.

Starting from the above conception of debate, the modern is defined here as the historical period (called modernity) that begins with the very institution of the world of significations that have been constitutive of the Western societies and lasts as long as these significations constitute positive sources of meaning that inspire and orient individual and social action and as long as they are embodied in and conveyed by the institutions of Western societies and the social practices that these institutions regulate. The postmodern could then be defined as an historical epoch (called postmodernity) that begins with the incipient alteration and decomposition of these significations, as the epoch when they cease to constitute a positive source of meaning for individual and collective action and for the institutional regulation of social practices. Thus, postmodernity does not necessarily need to convey any new significations, as positive sources of meaning, at least not explicitly, but emerges as the de facto decay of modernity, in the effective social life. In this case, we have just to recognize a fact or to quarrel about its true, to reflect around its reasons and its philosophical and political implications, and to deliberate about the political responsibilities that we are willing to undertake in relation to that fact.

However, the postmodern also refers to a broad and multiple intellectual currency (called postmodernism or postmodernist thought in juxtaposition to modernism or modernist thought) that not only affirms postmodernity as an historical fact, but also participates actively in a discursive problematization, questioning and even deconstruction of the significations and the institutions of modernity, inspiring in that way individual and collective action in different social fields of Western societies. In relation to this intellectual currency, we are legitimized to ask about the philosophical and political implications as well the about the political responsibilities that might follow from its deconstruction of modernity.

Which are then the significations of the world that constitute the epoch of modernity? What is at stake in the debate between modernism and postmodernism? Are the significations and institutions of modernity de facto in a state of decomposition? And which are the philosophical and political implications that we can draw from all these considerations? Drawing upon the work of Cornelius Castoriadis, I will try to elaborate some aspects of these questions. 


\section{The identity of the West}

The Western civilisations, in Castoriadis account, emerged through the creation, positing and partial institution of two central social imaginary significations which, as collective sources of social and subjective meaning, have formed the thinking-doing and speaking-acting of the Western societies as well as the institutions and the social practices that are particular to it. First, the signification of freedom, which emerged already from the $11^{\text {th }}$ and $12^{\text {th }}$ century by the protobourgeoisies' endeavour to selfgovern their cities and has been subsequently pursued in various forms, as a project of individual and collective autonomy, by different social movements, in their struggle for social, political and institutional change. Second, the signification of unlimited expansion of "rational mastery", which emerged with capitalism and its appropriation of the natural and social sciences and has been pursued by public and private bureaucracies as a project of unlimited development of science and technology and their embedment in a project of unlimited growth of production and consumption.

These two significations have impregnated with their meaning the languages of western societies, giving rise to the emergence of new significations, while simultaneously altering and changing the meaning of previous ones, such as, for example, the significations of equality and justice, and the signification of progress, as a ceaseless scientific, economic and social development. Moreover, they have given rise to, inspired and oriented all the great projects of the West. First, the political project of freedom and democracy, which, together with the associated significations of equality and justice, have infused, in different and contradictory ways, various social movements and the two great ideologies of the West, liberalism and socialism, and gave rise to a series of institutions - such as the institutions of the rule of law, of human rights, of parliament, of citizenship, of freedom of press and speech, etc,. Second, the philosophical and scientific project of accumulation of true knowledge about the world, which gave rise to the institutions of science, of education, of research institutions, and of professional expertises. Finally, the social-economic projects ceaseless growth and development, which intertwined in different ways with the aforementioned political and scientific projects, gave rise to the institutions of capitalism, the market, the business enterprise and the managerial bureaucracies, as well as the institutions of the welfare state and of state bureaucracies.

Thus, in a deeply ontological sense, the significations of autonomy and "rational mastery" have brought the West into being, constituting its distinctive and unique identity, as a particular civilization.

\section{Determinacy and the Reductionist Mode of Thinking-Doing}

What however underlies the above two central significations of the West is another signification, which is not particular to the West but rather universal in human history, namely the signification of the determinacy of the world. What is particular to the West is that this signification emerged under the form of Rational Reason, as a 
confidence that human Reason is capable to get true knowledge about the world. This Reason posits explicitly determinacy as an ontological assumption and as an epistemological presupposition for true knowledge and it also posits the equally explicit imperative to provide a the rational foundation of the sources of determinacy - rather than positing such a foundation from the very beginning, as the instituting act of society, which is the case with other civilizations. This imperative crosses along all the great project of the West, as an imperative to find the rational foundation of freedom, the rational foundation of scientific truth and the rational foundation of our social-economic strategies for growth and development.

The assumption of determinacy postulates that everything that exists (every form of being - nature, the living being, the animal and human psyche and the socialhistorical - and every subform belonging to these forms) can be defined, with regard to its elements, attributes and relations, in distinct and definite terms, and determined, with regard to its origin, in terms of equally distinct and definite causal relations. Determinacy presupposes and simultaneously implicates logically and ontologically the assumption of identity or unity of the world: that is, the existence of a universal essence (a first element or driving force) from which we can produce causally or deduce logically the entire multiplicity of forms of being that compose the world (from the physical reality, through the living being and the psyche, to the social-historical). This essence should than constitute the unity of the multiplicity of the world or, which is the same, the identity of its differentiation. Multiplicity is thus conceived as the effect of the determined differentiation of the identity of the world of the determined spatiotemporal unfoldment of the world's essence.

The assumptions of determinacy and identity/unity of the world form together the doctrine of reductionism. Simple reduction is the process by which we deduce logically or produce causally a phenomenon from another more general and therefore temporally preceding phenomenon, through necessary and sufficient logical or causal relations (e.g. the revolution of the earth around the sun is explained by - or is reduced to - the law of gravity). Evidently, scientific research should be impossible without this logic of simple reduction, which anyway lies at the heart of natural and biological sciences. However, if we then try to explain this more general phenomenon (the law of gravity) from another still more general, and this one from another even more general phenomenon, we are by logical necessity led to infinite regression. If gravity is explained by - reduced to -, say, the curvature of space and time brought about by every body, or by the exchange of baritone between bodies, what explains this curvature and what is a baritone? And what explains that which explains the curvature or the baritone? Infinite regression can be stopped only arbitrary, by assuming a universal essence, which do not need any further explanations and which is thereby posited as the origin and foundation of the world, as the original source of determinacy and unity-identity of the world.

Reductionism, on the other hand, in distinction from simple reduction, constitutes a doctrine that asserts that everything that exist and everything that can ever exist can be explained through reduction. It is this doctrine that leads us with logical necessity 
either to infinite reduction or to the idea of a universal essence and then to the idea of a universal determinacy and unity-identity of the world. And whatever can be explained through reduction, can in principle also be entered in relations of production by the technological transformation of cause-effect relationships to means-ends relations. Thus, reductionism and the assumptions of universal determinacy and unity-identity that underlie it form together what might be called a mode of thinking-doing of society, namely the reductionist mode of thinking-doing. Society, or individuals and collectives belonging to it, think about their natural and social world and engage themselves practically with it, as if it is determined by an essential source of meaning, which is posited as the source of unity-identity of society and the world. Simultaneously, society creates around this mode of thinking-doing various discursive and practical schemes of speaking-acting, upon which it articulates its discursive representations of its world - mainly, of its institutions and the social practices that they regulate - and instruments the practical means and ends of the individual and collective action that takes place within these practices. In a deeply ontological sense, society brings itself into being and constitutes its institutions and its social practices within a thinking-doing and speaking-acting that reduces the meaning that these institutions and social practices conveyed and embodied to whatever society posits as its essential source o meaning. An effective social word is created around what society posits as its essential source of meaning.

As noted above, and for reasons to which I will return subsequently, reductionism, as mode of thinking-doing, is rather universal to human societies. What is specific to the West, as also noted above, is the imperative to find a rational foundation of whatever might be posited as universal source of reduction. The reductionist mode of thinkingdoing emerged then in the Western world as a rationalist mode of thinking-doing. This imperative of rational foundation has also formed the discursive and practical schemes of speaking-acting that are specific to the western societies and which might be called the rationalist schemes of speaking-acting or the discursive and practical schemes of rationalism. What is specific to the discursive schemes of the West is that they make - and have to make - claims to scientific truth. Science in Castoriadis account, has been for many centuries established in the Western world as an instituted reality that is defined and based on four principles: (a) the principles of observable facts as the object of scientific truth, which claims "the production and reproduction of phenomena through experiment and observation"; (b) the principle of formal-logically correct inferences as the prerequisite of truth, which claims theories to be articulated as "formalisable (or at least partially formalisable) systems of inferred statements"; (c) the principle of "univocal correspondence between the former and the later", that is, between observable phenomena and theoretical statements, as the criterion of objective truth; and (d), the principle of verification, which claims that the results of science have to be communicable and thereby accessible to intersubjective control (conf. Castoriadis, 1978/1984, p. 4). The discursive schemes of rationalism are thereby based upon the scheme of simple reduction, as theoretical statements have to be deduced, by logical necessity, from a set of major premises, which are supposed to reflect the general laws or the driving forces underlying the observable phenomena under consideration, and a set of minor 
premises, which are supposed to define the specific conditions within which the general laws exercise their causal effects. In that way, the discursive schemes of rationalism are ceaselessly confronted with the impasses of reductionism, that is, with the problem of infinite regression and the spectacle of essentialism, to the extent that they have to give account for the origins and the truth of their major premises.

Around its discursive schemes of speaking-acting, the Western world has also instituted some practical schemes of speaking-acting. First, the practical scheme of critique, upon which discursive representations of social reality are compared to the effective social reality, to the effective institutions and to the effective social practices that these institutions regulate, in order to define deviation between the true essence (the major premises, the laws or the driving forces) of social reality and the effective social reality. Second, the scheme of politics upon which identified deviations between true essence and effective reality are transformed into political projects and strategies of intervention, in order to bring social reality in congruence with its true essence. Thirdly, finally, the practical scheme of instrumentality or policymaking, upon which the cause-effect relations that are posited by the discursive representation of the effective social reality, which is now assume to be more or less in congruence with its true essence, are transformed into means-ends relations that aim to increase the efficiency and effectiveness of social action, by adapting it to the ever changing specific conditions (the minor premises) of social practices.

\section{Modernity, Post-modernity and the Inescapable Ontological Paradox}

Modernity might be defined as the time period during which the above two central imaginary significations of the West - autonomy and "rational mastery" - are posited into the historical scene of the Western world, begun to inspire its various social and political movements, and become gradually articulated and instrumented into all its aforementioned great projects, and finally embodied in the institutions and social practices that these projects gave rise to. However, modernity is also the time period of the almost total domination of the reductionist mode of thinking-doing, as projects, institutions and social practices have been articulated and instrumented upon the discursive and practical schemes of rationalism. First, this is the case with the political project of freedom and the associated projects of equality and justice. Both the liberalist and the socialist ideology have tried to found - or reduce freedom on an extra-social and extra-historical essence. Liberalism founded it in the true nature of the human subject, which is essentially defined as the historically all the more successful strive to realize inner drives, formed into wishes and articulated into interests. Through infinite regression, this leads us to the "egoistic gene" and beyond that, to a still unknown, more general essence. Socialism, on the other side, founded freedom in the very nature of the social-historical, which consist in the class struggle between the exploiters and the exploited, which in itself reflects the unity and contradiction between the level of development of the means of production and the relations of productions. Freedom, in that account, is the outcome of this historical unfoldment of class struggle, namely of the classless society. It is defined as lack of exploitation and, moreover, as emancipation from the material conditions of 
human life - thereby, essentially, as leisure. Both ideologies conceive therefore individual freedom essentially as recognition of necessity - the necessity of institutions and social practices that safeguard, for liberals, the effective pursuit of individual interests and, for socialist, the emancipation from the material conditions of life.

It is not surprising, that both ideologies, confronted with the problem of infinite regression, define the foundation and the driving force of human history in the increasing rationalization of the human thought and action, gradually achieved by an increasing scientific approximation of the world and pursued as the unlimited expansion of the "rational mastery" over the world. For liberals, rational mastery is the precondition and simultaneously the means for the effective pursuit of interest, within the scope of exercise of individual freedom. For socialist, rational master is the precondition and the means for the emancipation from the material conditions of life, and then for the effective exercise of freedom as leisure. It is not either surprising, that both ideologies have had great problems to accommodate in their thought and practice the political project of freedom as collective autonomy or as democracy. For liberals, democracy makes it possible for the unprivileged and uneducated mob to abolish the institutions of individual freedom (mainly the institution of private property), while for socialist, the organization of class struggle and the building up of a classless society that is emancipated from the material conditions of life are effectively pursued not mainly by democracy but by the "scientific management" of a political avant-garde. Conceived as recognition of necessity, the project of individual freedom neither leaves any room for democracy nor can by guaranteed, as such a conception, by democratic processes. For both ideologies, democracy is tolerable to the extent that it does not question what they posit as historical necessity.

Second, the reductionist/rationalist mode of thinking doing also underlies the main philosophical and scientific projects of the West. It is true that the dominant strand of philosophy, positivism and analytical philosophy, confronted with the impasses of reductionism, has abandoned ontology as metaphysics and turned its attention towards epistemology. However, the main epistemological questions that it posited to find criteria for the verification of a univocal correspondence between the analytical statements of the scientific language and the synthetic statements of the empirical language - already presuppose an deterministic ontological nature on the part of the subject matters of science. Simultaneously, the claim for the epistemological unity of all sciences reintroduces the assumption of universal determinacy and thereby of reductionism. Moreover, the assumption of determinacy has also been extrapolated to the language of science and to language in general. The very principle of univocal correspondence presupposes a language that can be organized as a determined system of distinct and definite representation, which is assumed to correspond to an equally determined system of distinct and definite observations. The scientific projects of the West, on the other side, are effectively pursued upon the aforementioned four principles of scientific activity and the scheme of simple reduction that these principles convey and embody. However, they fall into mere speculation, every time they are tempted to unify their findings from different 
spheres into more general schemes of reduction.

Finally, the social-economic projects of the Western world have been, and still are, deeply immersed in the reductionist/rationalist mode of thinking-doing and in the discursive and practical schemes of rationalism. It might be argued that all the main political, social and economic institutions of Western societies and the social practices that they regulate have been brought into being, constituted and organized, as an effective social reality, upon the critical, political and instrumental schemes of rationalism.

In abstract terms, post-modernity could by defined as the time period when the two central significations of the West and the great project of modernity that they gave rise to have ceased to inspire the social and political movements of the Western societies, simultaneously as they are altered and changed as to their meaning in the institutional practices of the Western societies. Lyotar's proclamation of the death of meganarratives should epitomise such a period. Of course, the truth of this abstract definition is matter of empirical investigation, itself open to different interpretations, and I will return briefly to this matter subsequently. But post-modernity also refers to a factual, although internally diverse intellectual current that has as its common denominator the problematization and the questioning of the dominant mode of thinking-doing and schemes of speaking-acting of the Western world, and subsequently also of its great projects and their institutional embodiments. First, as an intellectual current, post-modernity had questioned and rejected the very notion of a universal and unified rational reason, showing that reason is based on premises that are fundamentally groundless, immersed in cultural contexts and determined by relations of power. Second, it questions the universal validity of the political, social and economic projects of the west, showing their confinement in the Western history, rejecting in that way the notion of a unified human history as evolution and progress toward freedom. Finally, the most general implication of this intellectual current is rejects the very signification of reductionism and the assumptions of determinacy and identity/unity of the world that are underlying it, showing that all attempts to construct such an identity/unity within all spheres of reality and knowledge have failed.

However, reductionism and the assumption of determinacy and identity-unity were subject matters of problematization and question from the very beginning, from their explicit articulation in ancient Greece, but also during the time period we defines as modernity. That is also why it is problematic to define postmodernity in terms of a time period. Nowadays, however, reductionism is not only questioned but is literally shattered, and that not primarily because of the postmodern deconstruction of it, but of the very development within its own fields.

On the one hand, it is shattered by the very development of natural sciences. Any attempt to build a formal mathematical system, whose true propositions could be reducible to a complete and non-contradictory set of axioms, has failed completely (for example, the paradox of Russell and incomplete proposals Gödel). Only this, the 
impossibility of reductionism at the very level of logics, should actually be enough as the fatal blow on reductionism on the ontological level. But reductionism cannot find any support in the hardest of all sciences, physics: the level of classical physics, for example, can not be reduced to the level of Quantum Mechanics, which means that the macrocosm can not be explained by the microcosm; and thermodynamics can not be reduced to molecular mechanics (or be explained by it). Nor can it stand in biology, notwithstanding its recent renewal following the results of DNA research: biological reality can not be reduced to physical reality and the emergence of new forms of life cannot be reduced into specific cause-effect relationships, but are conceived as a result of mutation (i.e. of something we do not know anything about). And, within the reductionist mode of thinking, what can we really say about the emergence of the psyche and the imaginary world of the human psyche?

On the other hand, reductionism has been shattered by the development of the very philosophical tradition and the theory of science that studied the logical structure of natural science in order to form the normative or descriptive principles of a unified methodology of sciences. What happened actually to the analytical philosophy and logical positivism? It can been argued that they have ceased to exist as alive traditions, as they have failed with their initial purpose, but by having first providing us with a series of invaluable knowledge which question and finally relativize all the aforementioned four principles of scientific research: there is no any logically univocal (i.e. distinctly and definitely determined) theoretical language; we cannot distinguish in a univocal way between a theoretical (analytical) and an empirical (synthetic) language; there are no logically univocal criteria through which we can verify or falsify theoretical (analytical) propositions by the empirical (synthetic) ones; and, most importantly, we can not compare in a logically univocal way a theoretical system (e.g., classical physics) with another (the theory of relativity or Quantum Mechanics), which also means that we can not deduce the one system from another, or reduce the one to other. Even less can we reduce biological concepts and categories to physical ones (not to mention the psychological and social-historical concepts and categories). This development amounted to a radical relativist conception of knowledge, which can be epitomized in the following expression: truth is what we expect to observe within a language game, a lifeworld or a scientific paradigm.

Finally, reductionism has no place any more in the socialhistorical sphere: we cannot explain the enormous diversity of civilizations as manifestations of a gradual evolution determined by a common nature. It becomes more and more evident that every culture constitute itself on the basis of instituted representations of the world, as they are articulated-instrumented into various social discourses, objectifiedconstituted into different fields of knowledge and practice, and codified-crystallized into various socially sanctionable norms of behaviour - and as these discourses, fields and norms are interwoven with relations and strategies of power. These representations are unique to every civilization, that is, not reducible to a universal substance, which also means that we have to start from them in order to understand the society under consideration. The social discourses of the West that still make claims to scientificity (e.g. neoclassical economic theory) start in reality, as to the 
axioms or major premises of their syllogism, from the instituted representations of the West (the economic or rational man, acting in a free market). To the extent that they become interwoven with relations and strategies of power (free markets as the object of economic policymaking), they bring into being and constitute the objective realty that they believe to reflect scientifically. Correspondences between theory and empirical observations are not measures of the theory's validity but of its effectiveness to constituting reality in its own image.

We are faced with two contradictory facts: on the one hand, reductionism, as well as the assumptions of determinacy and identity underlying it, have no place anywhere, neither in relations between the different types of being (nature, the living being, the psyche, the socialhistorical), nor within each one of these types. On the other hand, the previous types, in the above sequence, constitute the (necessary although not the sufficient) conditions of possibility for the subsequent ones, while, simultaneously, there is in each one of these types an infinite number of layers which are, each one, at least partly determined and therefore reducible in an identity-unity. On the one hand, therefore, a world of indeterminacy and otherness; on the other, we encounter densely everywhere in that world determinacy and identity-unity. We encounter these two contradictory facts also in the results of science: on the one hand, the incredible accumulation and deepening of real knowledge about countless of layers in all types being; on the other, the obvious impossibility to integrate this knowledge into a unity, not even within the one and the same type of being. We are faced with a central logical-ontological question: how is the mode of being of the world if it is a multiplicity of partially determined layers, which however cannot be reduced to a common identity-unity?

This question is not posited, neither by modernists nor by postmodernist, for it confronts us with a real paradox that we can not deal with within the reductionist mode of thinking: simple reduction is the logical consequence of the assumptions of determinacy and identity-unity; determinacy and identity-unity is "densely" presented everywhere in uncountable layers within all types of being; but these layers and these types are not reducible to each other, they do not comprise a determined identity-unity, they do not constitute a system or a system of systems. Simple reduction is possible everywhere, but it does not support reductionism, i.e. the doctrine that everything can be reduce to a universal substance. It is exactly this real paradox that constitute the pivot around which both modernistic and postmodernist are moving, although in opposite directions.

In a logical-ontological level, the postmodernist equates simple reduction (and the assumptions of determinacy and identity-unity) with reductionism and thereby rejects reduction together with reductionism, or conceives reduction as well as determinacy and identity-unity as exclusively discursive constructions. So, s/he is blind in front of the countless layers of being that are determined in themselves and determinable by us, and in front of the incredible accumulation of knowledge about these layers. Therefore, the principle of the postmodernist is: since there is no any universal foundation for reduction of the multiplicity of being, there is nothing. The 
modernistic, on the other hand, also equated reduction to reductionism, and accepts reductionism in front of the presence of the possibility of reduction. But $\mathrm{s} / \mathrm{he}$ is obliged to postpone the discovery of the universal foundation of the being for an indeterminate future, or to conceive this foundation as the truth that the cumulative growth of knowledge converges to, without ever being able to reach it. So s/he is blind in front of the abysses and gaps that sciences are confronted with every time they try to integrate the accumulated knowledge into an inherent whole. The principle of modernistic is: if there somewhere exists determinacy and identity-unity, then there must also exist a universal foundation for the reduction of the total multiplicity of being.

In a practical-political level, the metamodernists stigmatize, and rightly so, the fact that all totalitarian ideologies and regimes have built upon reductionism and have been exercised as carriers of absolute truth. They can proudly declare that the death of reductionism marked the death of hierarchy and authority. But they find it difficult to explain why they are in favour of freedom and democracy, against Auschwitz and against, for example, circumcision or hierarchy and authority. Since there is no any Archimedean point to hold on, all cultural norms are equally acceptable, because nothing is better than anything else: «anything goes». The modernists, on the other hand, the liberals as well as the socialists, are hounded by an internal and inescapable anxiety: if there is no any Archimedean point to hold on, how then should we change the world? If liberal democracy is not in congruence with the true nature of man, why should we defend it? And if it is not the inevitable and necessary outcome of socialhistorical laws, why should we fight for socialism? The modernistists must raise their own (Western) cultural values to universal truths about the nature of man and society in order to be able to pursue them, and as superior curriers of these truths, they believe that they can communicate with all other cultures (or subjugate them to these truths in the name of progress).

Within the universe of the reductionist thinking, we can not go further than so. Any attempt to answer the above question about the mode of being of the world by accepting its two terms - that the world consists of partially determined layers, which however cannot be reduced to a universal essence - leads us by necessity beyond the reductionists thinking, toward an other logical-ontology, toward other conceptions of the world. From what I know, it is only Cornelius Castoriadis that explicitly committed himself to the effort to develop a non-reductionist logic-ontology and explicate its philosophical, scientific-theoretical and political implications. Briefly, I can here develop only two of his central ideas.

\section{Being as magma and as creation and alteration of forms}

The first idea concerns that which is and the mode of its being, i.e. the nature of the world. The multiplicity of being is not only a result of the determined differentiation of identity, but also a result of the emergence of otherness, that is, of the creation of new, non-reducible forms, and of the change and alteration of these forms. This central idea of Castoriadis about being (whish also concerns history or time), as 
creation and alteration of forms, as the emergence of otherness, has two main implications.

On the one hand, creation implies the indeterminacy of forms, since the very emergence of a form (i.e. of a set of core elements, properties and relations and the very mode of their organisation) is undetermined. Any new form (the living being, the animal and human psyche, the social-historical) finds certainly a support or a lineage in previous forms, in the sense that they provide the necessary conditions of its possibility, but these conditions are not sufficient for its emergence. Therefore, the new form cannot be reduced to them: forms are not products of causal relations but emerge from zero (ex nihilo) - although not in zero (in nihilo) and not with zero (cum nihilo), but in something and with something. We cannot, for example, produce causally or deduce logically the living being from the physical reality, although the emergence of the former should be impossible without the existence of the later. A new form is therefore not a product of differentiation of an initial identity but of the emergence of otherness - of a non-reducible "other". So, as to the multiplicity of forms, Castoriadis juxtaposes or, more correctly, superimposes the emergence of otherness to the differentiation of identity, and creation to determinacy.

On the other hand, creation implies the emergence of a new determinacy, because the emergence of a new form involves the creating new elements, properties and relations and of new modes of organization, thus of a new source of determination, of a new unity-identity that can be differentiated, or, if you like, of a new "substance" that can be developed and multiplied. In other words, the emergence of a form involves the emergence of a new layer of being which is created (brought into being, constituted, organized) by this very form (by its elements, property and relations and by its mode of organisation) as partially or indefinitely determined. The determinacy of a new layer is indefinite because the form that brought it into being is, on the one hand, non-reducible, and must therefore always be taken for granted, and, an the other, inexhaustible, because it gives rise to the creation of an indefinite number of new, equally non-reducible subforms and therefore of new, equally indefinitely determined sublayers (e.g. the living being, the multiplicity of non-reducible forms of life that it creates, as well as the multiplicity of subforms that constitute every living being - smell, pain, pleasure, vision, metabolism, reproduction, gender differentiation, etc.).

As a consequence of creation, and at the same time as its precondition, being is not organized as an ensemblistic-identitary (or ensidic, in Castoriadis' neologism) system or system of systems but as a magma: a fragmented and stratified unity of indefinitely (i.e. irreducibly and inexhaustibly) determined layers. These layers contain an ensidic dimension, that is, a dimension of determinacy, therefore also of reduction, but they are irreducible and inexhaustible as to the forms that brought them into being and organize them and as to the subforms and sublayers that can emerge within them. To the ensidic logic-ontology, which is based upon the assumptions of determinacy and identity-unity and which forms the reductionist mode of thinking-doing of society, Castoriadis juxtaposes the magmatic logic- 
ontology, which is based upon the assumptions of creation and otherness and which forms a non-reductionist mode of thinking-doing of society. Or more correctly, he superposes the magmatic logic-ontology to the ensidic one, since every layer of being always contains an ensidic dimension, without however being completely determined or exhausted be it.

The magmatic logic-ontology developed by Castoriadis has some highly imported implication both for the theory of knowledge and for the discursive and practical schemes of human intervention into the physical and biological reality. Briefly, the accumulation and deepening of scientific knowledge about all the uncountable layers of the physical and biological being, pursued upon the aforementioned four principles of scientific research, is possible exactly because these layers are partially determined in themselves. But this knowledge can only concern the ensidic dimension of these layers and can never comprise their magmatic "residual"; it must always take for granted the forms and subforms that bring into being and organize every layer; at best, it can explicate the conditions of possibility, the lineage or the support that these forms find in other forms and layers in order to emerge, multiply and differentiate themselves, but it can never explain their very emergence; therefore, science can never unify knowledge about different layer to a coherent theory. And that not only and not mainly because of the inescapable circumscription of our knowledge by our language games or because of the inherent indeterminacy of our language, but because of the ontological indeterminacy of the emergence of forms. Likewise, to the extent that we articulate and instrument that knowledge into schemes of practical intervention into the physical and biological reality, we can partially control only the ensidic dimensions of that reality and eventually engage ourselves with the precarious endeavour to manipulate the conditions of their possibility. But we can never control the magmatic residual within which new forms emerge, are altered and vanished.

The second central idea in Castoriadis' thought concerns the social-historical. If being in general is creation and alteration of forms, the social-historical being is creation and alteration of social forms: that is, of social imaginary significations and of institutions which convey and embody these significations in the social practices that they regulate. We encounter here Castoriadis' conception of the imaginary as constitutive of the social-historical and also of the human subject (or psyche), which I will not elaborate here. Every society or civilization brings itself into being and constitute itself, as that particular civilization, by creating, positing and instituting a magma of social imaginary significations (god, freedom, equality, justice, the rule of law, rationality, progress). These significations are significations and not simply ideas or representations because they constitute an inexhaustible source of emergence of social meaning - and a source of emergence of ideas and representations. They are imaginary, because they are neither outcomes of rational or functional determination nor have any referent in any empirical reality - they rather provide the sources of meaning in relation to which something can be rational or functional for the society in question, and society has always to bring into being what it accounts as their real referents. In that sense, they are creations ex nihilo, 
unmotivated and irreducible to any cause and have therefore to be approached and elucidated as such. They are social, because they are instituted in the form of language and are therefore shareable by all members of society. Finally, they are constituted as magma, because the significations of language are indefinitely (that is, irreducibly and inexhaustibly) determinable without therefore being determined: we can always define the meaning of the signification "god" or "freedom", but we can never reduce them to any true ground or exhaust their meaning. The human language is therefore inherently undetermined because it is comprised by imaginary significations which are organized as magmas of meanings.

However, every society has to define the meaning of its significations to a sufficient degree in order to constitute its institutions and thereby embody and convey them in the social practices that these institutions regulate. The processes of definition are historical processes of significative and institutional closure, whereby the significations of society are articulated-instrumented into discursive and practical schemes of speaking-acting, concerning its various discursive domains, are objectified-constituted, within these domains, into real fields of knowledge and practice, and are codified-crystallized, within these fields, into sanctionable norms of individual and collective behaviour. These domains, fields and norms constitute the "second-order" institutions of society. A magmatic world of indeterminacy is closed into an instituted world of sufficient determinacy, partially organized into ensidic systems, as to allow for instrumental means-ends relations and functional adaptations. However, these processes of closure cannot be outcomes of purely rational considerations or functional adaptations, for rationality and functionality already presuppose a significative and institutional closure in relation to which something can be rational or functional. Moreover, the closure pursued by society can never be absolute, as society is always confronted with the magmatic meaning and the inherent indeterminacy of its significations, and with the inherent incongruence between any meaning and the social and physical reality - the insidic systems - that society has constituted-organized around that meaning, as its real referents. So, society has to ceaselessly produce and reproduce the processes of its significative and institutional closure.

In Castoriadis' account, these processes of closure constitute the political dimension of society and are therefore always mediated by the explicit power of society, which constitute a universal mode of organization of society. In the last instance, it is always power, not rationality or functionality, that transforms indeterminacy to determinacy. But the explicit power of society is not completely arbitrary. The processes of closure are also mediate by two rather universal principles of organisation of society. First, every society or civilization brings itself into being by creating, positing and instituting some central social imaginary significations. These significations are central, in the sense that they impregnate with their magmatic meaning the totality of significations of society and its language as well as the totality of its institutions and social practices. They provide the source of meaning for the closure of all other significations of society. Every society creates, so to say, the specific principles of its own organisation, in the form of central imaginary 
significations. These significations indefinitely circumscribe a world of meaning which comprises the infra-power of society - a power that indefinitely circumscribes the forms of explicit power that are possible in that society, in the sense that any explicit power can make claims to legitimacy only to the extent that it also makes claims to convey and embody the world of meaning circumscribed by these significations. Secondly, the processes of closure are also mediated by a reductionist mode of thinking-doing of society, whereby social practices, the institutions that regulate them and the significations that they embody and convey are reduced to a universal source of true meaning, a source that is always provided by the central imaginary significations of society. Reductionism is a universal mode of thinkingdoing of society and a universal principle of organisation of society.

The explicit power of society mediates then the processes of closure within and through a reductionist mode of thinking-doing, by reducing the discursive and practical schemes of speaking-acting that it pursues to a true source of meaning, which is always posited by the central imaginary significations of society. This mediation brings also about an organizational closure of society, as the forms of exercise of explicit power become also the forms of organization of its institutions and its social practices. As a consequence of the significative, institutional and organisational closure, pursued upon the principle of reductionism, every society brings itself into being and exists in and through a state of heteronomy, in the sense that it perceives its institutions, the significations that they convey and embody and the forms of explicit power that mediate them as descending from an unquestionable and unchangeable extra-social and extra-historical source of meaning (totem, god, biological or social-historical laws).

Every civilization in human history is then unique. There are certainly aspects that are universal - after all, we are all belonging to the same form of living being. So, every civilization exist in and trough two dimensions, an imaginary one, which is comprised by its universe of significations, and an ensidic one, which is comprised by its institutions through which it organizes its functional-instrumental relations with its physical and biological environment in order to ensure the biological survival of its members. We also encounter in every civilization the processes of significative, institutional and organisational closure, their mediation of explicit relations of power, the reductive mode of thinking-doing and the state of heteronomy. On the ensidic dimension, certain kind of communication is possible between civilizations. And only at that dimension is it possible to speak about some kind of comparison between them, in terms of knowledge and development - that is, in terms of their capacity to transform true knowledge about the physical and biological reality to instrumental means-ends relations, something that in the last instance is determined by their capacity to exercise force upon each other. On the imaginary dimension, however, every comparison is meaningless, except when we project - and impose - the significations and institutions of one civilization upon another. Moreover, and as a consequence of closure and heteronomy, every communications at that dimension is, if not impossible, at least extremely limited and always problematic. That is way the "other" is always perceived as threat, as a (superior, inferior or equal) enemy, which 
out to be hold in distance, converted, assimilated or extinguished. Racism, in Castoriadis' account, emerges when the presence of the "other" implies such a threat against ones own individual and collective identity - ones own imaginary world of significations - so that it is not enough to hold the other in distance but s/he must be extinguished.

\section{The unfinished project of modernity}

What, in Castoriadis' historical interpretation, is unique with the ancient Greek civilization is that it emerged within and through a radical break with what until than, and in a sense until now, has been a universal principle of organisation of society, namely, the reductionist mode of thinking-doing and, consequently, the heteronomy of society, which follows from the reductionist processes of significative, institutional and organisational closure. The ancient Greek world emerged within and through a mythological and, in Castoriadis judgment, deeply true conception of the world as a fundamentally undetermined Chaos. In that conception, any emergence of order (cosmos) is arbitrary, temporal and inescapably deemed to destruction. And this is equally true for Gods as for human beings, for their societies and their institutions. As a central social imaginary signification, this conception of the world provides no any source of meaning for reduction of the institutions of society, no any principle of organizations of society, no any source of legitimation of the explicit powers of society. There are no certainties, there is no hope. Distraction and definite death is the only certain destiny of every being.

Upon this conceptions of the world (and in contrast to the postmodern thought, which adopting this true conception more than two and a halve millennia later, fell into a political embarrassment), we encounter in ancient Greece the creation of philosophy, as a ceaseless and limitless project of interrogation and questioning of the institutions of society and the world of significations that they convey and embody, the creation of politics, as a project of explicit and conscious institution and reinstitution of society, and the creation of the signification of freedom, pursued as a project of individual and collective autonomy. And we also encounter the creation of the two main institutions that embody and convey the project of autonomy, the institutions of polis and, subsequently, the institution of democracy. The creation of politics, as democratic politics, has had two important implications. First, it implied a radical transformation of a universal mode of organisation of society: the political dimension of society, that is, the very processes of closure and the explicit power that mediates them, are transformed into a subject matter of the reflective and deliberate activity of citizens, with the explicit aim to render the instances of explicit power accessible to all citizens. This transformation was predicated upon the creation of a public sphere for the reflective and deliberate activity of citizens. A sphere where citizens were submitted to the claim of logon didonai, of being accountable for their public responsibilities and of giving account for their public opinions, in rational, that is, logically coherent terms. A sphere also where citizens explicitly conceived their presence as partially depending on their previous, individual and collective choices, and their future as partially depending on their current choices. Second, it implied 
the emergence of a unique principle of organisation of society, namely, the collective will or doxa of citizens, as it is each time formed and reformed within the public sphere by their reflective and deliberate activity. As there is no any external source of foundation and reduction of the processes of closure of society, the reflective and deliberate doxa of citizens is posited and instituted as such a source, constituting in that way a project of autonomy, which holds society in a state of ceaselessly suspended closure. It is that doxa that Plato has tried to replace by the episteme, the scientific knowledge of his king-philosophers, reintroducing in that way the reductionist mode of thinking-doing, now in the form of episteme, in the ancient and in the modern - world.

As it has already been mention above, the Western civilization emerged by recreating the signification of freedom, as individual and collective autonomy, but together with another signification that inherently contradicts it, the signification of the unlimited expansion of the (pseudo-)rational (pseudo-)mastery of the world - and that both emerged within a reductionist mode of thinking-doing, which is now formed as rationalism, aiming to find a rational foundation for both freedom and mastery.

Tracing the historical emergence and the trajectory of these significations, Castoriadis (1992/1997) distinguishes between three periods in the history of the Western Europe. The first period, called The emergence (constitution) of the West, is ranging from the twelfth century to the early eighteenth century. He traces the reemergence of the project of political and intellectual autonomy in the selfconstitution of the protobourgeoisie, pursued as a project of self-governance of its cities. This was "accompanied be new psychical, mental, intellectual and artistic attitudes that prepared the ground for the explosive results of the rediscovery and the reception of Roman Law, Aristotle, and then the whole of the extent Greek legacy" (Ibid, p. 36).

The second period, called The critical ("modern") epoch: autonomy and capitalism, is ranging from the middle of the eighteen century to the middle of the twentieth century. Modernity (although in quotes) is "best defined by the conflict, but also the mutual contamination and entanglement" between the two imaginary significations of the West, autonomy and "rational mastery", which emerges during this period as the imaginary signification of capitalism. What characterises this epoch, which became self-conscious with the Enlightenment, is a restless tension between a radicalized project of autonomy, which was conveyed by different social movements within all fields of society (political, socioeconomic, intellectual, etc.), and the development of capitalism and its project of "rational mastery", which has been embodied in the institutions of capitalism and is conveyed by their managerial bureaucracies. "The real expression of this tension is the development and the persistence of social, political and ideological conflicts", but also “...the hectic cultural and artistic creation of the "modern" epoch" (Ibid, 39).

Besides their tensions, however, both autonomy and rational mastery coexisted "under the common roof of "Reason"”, both being immersed within the reductionist 
mode of thinking-doing and pursued upon the rationalist schemes of speaking-acting. What marked the entry of the Western societies to a third phase (form about 1950) is in various ways a consequence of this enclosure into the discursive and practical schemes of rationalism. On the one side, the two world wars, as results of the pseudorational pseudo-mastery of the world; on the other, the emergence of totalitarianism and the collapse of the worker's movement, as result and condition of the slide of the socialist project of autonomy into Leninism-Stalinism; and as a common effect, the decay of the mythology of progress. What characterise this third epoch, called by Castoriadis The retreat to conformism, is the "waning of social, political and ideological conflicts", accompanied by an increasing "individualism", privatization and depoliticization, and by a deep distrust regarding all the instituted powers of society. And all that followed by a "decadence in the field of spiritual creations": in philosophy (where, "historical and textual commentary on and interpretation of past authors have become the substitute of thinking", theorized as "hermeneutics" and "deconstruction"), in science (which continues with the accumulation of knowledge, but basically upon the theoretical achievements of the previous period), and in culture and arts (where the principle of collage, "eclecticism and the recombining and reprocessing of the achievements of the past have now gained pride of program") (Ibid, p. 39-40). Simultaneously, we have the increasing domination and globalization of the capitalist imaginary of "rational domination" and the expansion and globalization of a capitalism which, now without any effective internal opposition, have become a "different social-historical animal". This development is expressed by the almost total domination of the new-liberal political and economic thought and the unlimited expansions in all fields of social practice of its two inherently, up to stupidity, contradictory projects - of market competition and managerial bureaucratization. A development that also involves a radical redefinition of the signification of individual freedom, from autonomy to a freedom of choice among multiple products and services and among multiple opportunities of instrumental action - subjugating in that way the project of freedom to the project of "rational mastery".

Postmodernism, in Castoriadis account, both as an effective historical trend and as a theory, is identified with this third period of conformity. And his verdict is devastating. As a theory, postmodernism "mirrors the prevailing trends", providing them with a "philosophical" justification or "blessing". As an historical trend, it reproduces conformity, as all this talk about "pluralism", the "respect for the difference of the other", and the glorification of eclecticism provide a generalized version of the "anything goes" principle and amounts to an "enthusiastically adhering to that which is there just because it is there". Drawing upon an article by Johan Arnason, The Imaginary Constitution of Modernity, Castoriadis first provides a summery description of the theoretical and philosophical tenets of postmodernism and then ends up with the following conclusion: "What we have here is a collection of half-truths perverted into stratagems of evasion." This conclusion requires some explication.

In a basic level, Castoriadis shares the critique of postmodernist against the 
modernist Reason, and its rootedness in rationalism and reductionism. Although it is historically more correct to say that the postmodernists share this critique with him. All that Castoriadis has wrote during the fifties in Socialisme ou Barbarie (a journal well-read by France intellectuals) amounted to a radical critique of the "rationalism" of capitalism and totalitarianism (of the fragmented and totalitarian bureaucracies respectively), a critique that, after his break with Marxism, about the turn of the sixtieths, (a note about his conflict with Lyotard in 1963?), was directed against the whole reductionist tradition that have dominated the Greco-Western though from the time of Parmenides and Plato. However, Castoriadis was not pleased with a simple deconstruction of that tradition. As I have tried to show above, confronted with the aporias that was constantly generated by that tradition and with the paradoxes of our knowledge, he set upon, from the early sixtieths, a project to develop an alternative logic-ontology of being in general and of the social-historical being and the human subject in particular. But this philosophical project was throughout impregnated by his political concern with the project of autonomy, something that led him to an explicit project to "reconstruct the horizon of thought [that is, rationalism and reductionism] within which the political movement of emancipation has been situated for centuries". This made it able for him to trace the historical origins of autonomy in these two unmotivated and rather improbable social-historical creations, in ancient Greece and the post-medieval Europe, providing in that way an alternative historical interpretation of the Greek legacy and the emergence of the West - and an alternative horizon of thought for the situation of the project of autonomy. These two projects have been almost in unison neglected by the great part of the France intellectuals, including postmodernist, who avoided them even as a subject matter of their deconstruction. What postmodernists evade is the critique of the current institution of society from the point of view of the project of autonomy. Proclaiming, and correctly, its relativity, they ascribe to it the same validity as anything else.

Addressing to Habermas' The Philosophical Discourse of Modernity, Castoariais remarks that it is not sufficient to say, "Modernity is an unfinished project".

Insofar modernity embodies the capitalist imaginary signification of the unlimited expansion of (pseudo-)rational (pseudo-)mastery, it is more alive than ever, and it is engaged in a frantic course pregnant with the severest dangers for humankind. But insofar as the development of capitalism has been decisively conditioned by the simultaneous deployment of the project of social and individual autonomy, modernity is finished (Ibid, p. 43).

Of course, the unfinished project of modernity is the project of social and individual autonomy. But for Castoriadis, it is not a matter of returning back to the programs in which it had been embodied during modernity (liberal republic or Marxist-Leninist "socialism"). "For the resurgence of the project of autonomy, new political objects and new human attitudes are required". It might be added that as a condition and as a first step toward it, the resurgence of the project of autonomy also requires another mode of individual and social thinking-doing, beyond the reductionist one. We might 
therefore talk about a post-reductionist epoch, not as the epoch in which we live, here and now, but as the one we ought to pursue, as the one we out to create. Nonetheless, both modernists and postmodernists are enclosed in the reductionist mode of thinking-doing - the one by confirming it, the other by rejecting it. For the postmodernists, the death of God (reductionism) marked the death of hope (as if hope presupposes an external foundation). The modernists, on the other hand, both the liberals and socialists, stubbornly keep their faith in God, in order to continue to hope. We must tell to the postmodernist: we want autonomy because we live in a civilization that has created it and therefore offers it as option of choice and because we choose is. And we must tell to the modernist: we choose autonomy, not because it can be ground in any nature, but simply because we want it - even against any possible nature that could counteract it. And we hope that when people from other civilizations will get the option of choice, they will choose autonomy, because they will want it.

Fotis Theodoridis is lecturer in Business Studies at Södertörns University College, where he is teaching since 1999. He is working on a thesis, entitled "Power, Discourse and the Imaginary", which elaborates on the work of Michael Foucault and Cornelius Castoriadis and which is part of a broader research interest in the forms of organization and governess of collective activity. 